Tomas Kliestik,

Professor, University of Zilina, Slovak Republic

D ORCID ID, 0000-0002-3815-5409,

email: tomas.kliestik@fpedas.uniza.sk

Elvira Nica,

Professor, Bucharest Academy of Economic Studies, Romania

iD ORCID ID, 0000-0002-8368-8028,

email: popescu_elvira@yahoo.com

Peter Suler,

Ph.D., Institute of Technology and Business in Ceske Budejovice, Czech Republic

email: 24786@mail.vstecb.cz

Katarina Valaskova,

Ph.D., University of Zilina, Slovak Republic

ORCID ID, 0000-0003-4223-7519,

email: katarina.valaskova@fpedas.uniza.sk

Correspondence author: tomas.kliestik@fpedas.uniza.sk

\title{
INNOVATIONS IN THE COMPANY'S EARNINGS MANAGEMENT: THE CASE FOR THE CZECH REPUBLIC AND SLOVAKIA
}

Abstract. Earning management is a collection of managerial decision that results in not reporting the true shortterm, value-maximizing earnings as known to management. It is focused on the changes in financial reporting to mislead the stakeholders and achieve contractual benefits. Earnings management emphasizes the manipulation of accounting choices and operating cash flows, and it is known as a practice which chooses an accounting treatment that is either opportunistic (maximizing the utility of management only) or economically efficient. The paper deals with the possibilities of detection and quantification of trend, degree and scope of the earnings management of Slovak and Czech companies from 2015 to 2017. The paper aimed to create a systematic overview of the earnings management specificities considering the enterprises' innovation policy as the phenomenon of earnings management understood ambiguously, contradictory and without consensus. The paper is to explain various opinions of earnings management understanding and to propose methodical instrumentation for the detection and quantification of earnings management. The validity of the focus in question is multiplied by the possibility of smooth implementation in the transition countries, countries that even after almost thirty years of transformation, still show a significant degree of difference from countries with a developed market economy. In total, 29 earnings management detection models were subjected to forensic analysis. 2,155 Slovak and 4,842 Czech enterprises represented the statistical sample after the removal of extreme values. The most effective model to reveal manipulation with earnings is the Kothari model. Using the Friedman non-parametric test, trend, degree and scope of earnings management were tested. The results of the analysis showed interesting results - countries tend to manipulate earnings upwards. Detection of earnings management practices in enterprises is of vital importance provided that the real and correct data have to be presented to stakeholders and third parties to prevent any forms of financial and credit risks.

Keywords: earnings management, earnings management detection models, discretionary accruals.

Introduction. Profit is a kind of reward for taking on business risks. There are several ways to use profit. Businesses, especially after troubled years, try to use the actual profits to save the capital structure by reimbursing the losses of previous periods. The interest of individuals partners is also different; a shareholder who is primarily concerned with the payment of dividends, an employee who is interested in increasing their motivation in the form of shares in the economic result, investments in improving the

Cite as: Kliestik, T., Nica, E., Suler, P., \& Valaskova, K. (2020). Innovations in the Company's Earning Management: The Case for the Czech Republic and Slovakia. Marketing and Management of Innovations, 3, 332-345. http://doi.org/10.21272/mmi.2020.3-24 
T., Kliestik, E., Nica, P., Suler, K., Valaskova. Innovations in the Company's Earning Management: the Case for the Czech Republic and Slovakia

working environment, increasing corporate funds, etc. Management, in addition to its bonuses, expects investments in new equipment, technologies or an increase in statutory funds. Thus, managing profits is an opportunity to generate higher revenues at certain costs and thus maximize profits (Stefko et al., 2019). The phenomenon of earnings management has become a crucial research topic in the field of accounting and financial decision-making. Empirical studies document different approaches to determine the behaviour of entities in managing profits. This trend is an increasingly attractive issue from several perspectives. Due to various accounting scandals, earnings management has become topical in discussions about the credibility of financial markets. Analysts and managers are interested in the latest practical and theoretical findings and studies related to the detection of earnings manipulation.

Ye (2006) determines earnings management as a tool to present a complex positive overview of corporate financial health and its business activities. Financial reports are legally modified using different techniques. As defined by Healy (1985), earning management is reasonable and legal management decision-making and reporting intended to achieve stable and predictable financial results. Earnings management helps to achieve specific targets involving the manipulation of accruals through discretionary choices (Krajnak, 2019). Thus, the emphasis is given to accrual earnings management, which does not influence the underlying corporate economics but involves the change in the accounting presentation of these economics (El Diri, 2018). For the first time in history, the term earnings management was used by Hepworth (1953). Since then, the investigation on the earnings management has made significant progress. The work of Healy (1985) should be mentioned as the author used the average total accruals for the first time to estimate the discretionary accruals (DA), and therefore to estimate earnings management. During the following years, authors increasingly treated the issue of earnings management. Table 1 summarizes the papers, which influence significantly the development of the earnings management (EM) research (only the highly cited papers over the years were considered).

Table 1. Milestones of earnings management investigation

\begin{tabular}{lll}
\hline Authors & Year & Brief description \\
\hline Watts and Zimmerman & 1986 & Earnings-based compensation agreements \\
DeAngelo & 1986 & Incentives to reduce buyout compensation \\
McNichols and Wilson & 1988 & Provisions for bad debts \\
Schipper & 1989 & Asymmetry - management vs. shareholders \\
Jones & 1991 & Import relief incentives to manage earnings \\
DeAngelo, DeAngelo and Skinner & 1994 & High levered companies tend to manage earnings \\
Defond and Jiambalvo & 1994 & Debt covenant violations \\
Dechow, Sloan and Sweeney & 1995 & Alternative models to detect earnings management \\
Holthausen, Larcker and Sloan & 1995 & Use of real earnings management techniques \\
Burgstahler and Dichev & 1997 & Avoidance of earnings decrease and losses by EM \\
Teoh, Welch and Wong & 1998 & Report on higher net income \\
Healey and Wahlen & 1998 & Definition of earnings management \\
Degeorge, Patel and Zeckhauser & 1999 & Earnings management to exceed thresholds \\
McNichols & 2000 & New approach: a principle of aggregate and specific \\
& & accruals, distribution of earnings management \\
Peasnell, Pope and Young & 2000 & Cross-sectional estimation procedure \\
Yoon and Miller & 2002 & Effect of operating performance of DA \\
Skinner and Sloan & 2002 & Hide real image of the company \\
Klein & 2002 & Importance of audit committee \\
Xie, Davidson and DeDalt & 2003 & Role of the board of directors in preventing EM \\
Leuz, Nanda and Wysocki & 2003 & Investigation on investor protection (31 countries) \\
Burgstahler, Hail and Leuz & 2006 & Capital market pressure \\
\hline
\end{tabular}


T., Kliestik, E., Nica, P., Suler, K., Valaskova. Innovations in the Company's Earning Management: the Case for the Czech Republic and Slovakia

\begin{tabular}{|c|c|c|}
\hline & & Continued Table 1 \\
\hline Roychowdhury & 2006 & Real activities manipulations \\
\hline $\mathrm{Ye}$ & 2007 & Cross-sectional vs. time-series models \\
\hline Jeanjean and Stolowy & 2008 & Impact of IFRS standards on EM \\
\hline Yague et al. & 2009 & Variation of stock market price and EM \\
\hline Callao and Jarne & 2010 & Effects of IFRS on EM \\
\hline Barth and Taylor & 2010 & Assets securitization and EM \\
\hline Chen et al. & 2010 & Sophisticated investors and EM \\
\hline Nwaeze & 2011 & Incentives of EM \\
\hline Okamoto & 2011 & Collective intentionality and EM \\
\hline Rodrigues, Marques and Craig & 2011 & EM induced by tax planning \\
\hline Alhadab, Clacher and Keasey & 2015 & EM activities and IPO failure risk \\
\hline Cimini & 2015 & 2008 financial crisis and EM \\
\hline Kothari, Mizik and Roychowdhury & 2016 & $\begin{array}{l}\text { Earnings management in seasoned equity offering } \\
\text { valuation }\end{array}$ \\
\hline Lo, Ramos, Rogo & 2017 & EM and annual report readability \\
\hline Collins, Pungaliya and Vijh & 2017 & Effect of firm growth on EM \\
\hline
\end{tabular}

Source: developed by the authors.

The newest findings in the field are focused on various issue. However, usually, the authors try to reveal the motives and incentives of earnings manipulation. Ding et al. (2018) suggested that politically affiliated enterprises were more likely than non-affiliated enterprises to engage in real activities to manipulate earnings. The mutual dependence between accrual and real earnings management is investigated by Hamza and Kortas (2019). The findings of Campa (2019) confirmed that the enterprise listed on the stock exchange is more affected by the income-increasing earnings management behaviours compared to unlisted enterprises. The mutual dependence between social trust environment and earning management is investigated in the research of Chen et al., (2019). Following the latest research, the originality of the research lies in exploring the issue on earnings management in Slovak and Czech economic conditions. The incentive is to analyse if the countries manipulate earnings. If yes, to measure the direction of manipulation (upward or downward manipulation of earnings) and the changes of manipulation over the years. The determination of the presence of earnings management help to reveal the motives of earnings manipulation.

The main objective of the paper is to clarify the questions of the earnings management in a crosssectional analysis considering the unique country samples of Slovak and Czech business entities. Thus, the paper aimed to quantify the variant of earnings management detection models in the condition of both countries, Slovakia and Czechia, where the phenomenon of the earnings management has not been explored yet. The results of the study may extend the theoretical knowledge and practical implication of earnings management in both countries.

The paper is divided into three main parts. The Methods section describes the dataset of enterprises entering the analysis and the linear regression detection models used to reveal the manipulation with corporate earnings. This section also specifies the methodological steps of empirical research. Results and Discussion section is focused on the description of all findings, resulting in the suggestion of the model, which should be used in the specific conditions of the selected countries to detect problems with earnings manipulation. Section Conclusions unveils the major findings and suggests the future orientation of the research in this field.

Methodology and research methods. Data for this analysis were obtained from the Amadeus database operated by Bureau Van Dijk (BvD). Sampling criteria were adapted to the goal of this paper. The database was formed of those enterprises, whose sales are higher than $3,000,000 €$, the value of total assets is higher than $5,000,000 €$, and their profit is more than $100,000 €$ in the period 2014 to 2017. 
T., Kliestik, E., Nica, P., Suler, K., Valaskova. Innovations in the Company's Earning Management: the Case for the Czech Republic and Slovakia

6,700 Czech and 2,769 Slovak enterprises met these criteria. However, not all the variables were available for every year and every enterprise. Therefore, the data had to be sorted out and incomplete and missing data discarded, and outliers eliminated, the final databased consists of 4,842 Czech and 2,155 Slovak enterprises. The main effort of the analysis is to determine and describe the model, which is the most suitable in the conditions of these countries when revealing the manipulation with earnings. Analysis of available relevant literature sources identified 29 models suitable for the detection of earnings management. Earnings management models use divergent input variables, and only those should be used to reveal the manipulation with earnings, which information values are the most accurate. The research methodology was as follows:

1. In the analysis, the first step was to choose an appropriate earnings model. Accrual-based earnings management aims to obscure true economic performance by changing accounting methods or estimates within the generally accepted accounting principles. Real earnings management alters the execution of real business transactions. Thus, the focus is on the models of accrual-based earnings management and therefore, it was necessary to exclude the models of Roychowdhury (2006), Gunny (2010) and Zang (2012). The appropriateness of using earnings models for assessed in the next step and models of Healy (1985) and DeAngel (1986) were removed. Both authors assumed a non-discretionary accrual consistency and, at the same time, imply the level of manipulation, a thus it is not possible to judge their strength. Furthermore, the model of Ronen and Sadan (1981) was excluded because they do not rank the overall accrual. Some variables were not available. Thus, those earnings models were excluded from the further analysis.

The component model (Kang and Sivaramakrishnan, 1995) was removed from further analysis due to an undetectable variable (economic operation costs). Other models were given out of the analysis as the information about all the variables entering the model was not available in the database. Herewith, the model by McNichols (2002) was not considered due to several variables which were not provided in the Amadeus database. In turn, in the synthetic models of Ye (2006) and Yoon and Miller (2002), nonmonetary working capital and economic operation costs could not be determined for all analyzed enterprises. The Beneish model (1997) was not applied due to the undetectable value of corporate fixed costs. The model of Larcker and Richardson (2004) lacks the market value. The Stubben (2010) model was not taken into account due to missing quarterly data on revenue development. Except for the described ones, these models were also not considered due to missing or undetectable data, industrial model (Dechov and Sloan, 1991), Margin model (Peasnel et al., 2000), Pae model (2005), Dunmore model (2013), Spathis model (2002), Dechow and Dichev model (2002), Hribar and Collins model (2002), etc. Finally, seven models were chosen to be analyzed (Table 2) as calculation of other models was not possible due to the missing or not available data in the Amadeus database.

2. Suppose the most appropriate model has to be chosen. In that case, each model needs to be assessed following the relevant statistical measures: adjusted $\mathrm{R}$ squared, predicted sign of variables, the standard deviation of the variables and significance level of the model and its variables, statistical significance were tested at $5 \%$ significance level (Valaskova and Durana, 2020).

3. Based on the most relevant earnings management detection model, the discretionary accruals are estimated. Besides, the direction and extent of manipulation are detected together with the sign, magnitude and dimension of earnings management using the proportional ratio and means of absolute values of positive and negative discretionary accruals.

4. The changes in the earnings manipulation over the years are calculated by the non-parametric Friedman test (the normality of the dataset was not confirmed). Suppose there is a significant difference over the years. In that case, the p-value of the Friedman test is less than the significance level 0.05 , and it can be claimed that the distribution of discretionary accruals over the years are not the same. 
T., Kliestik, E., Nica, P., Suler, K., Valaskova. Innovations in the Company's Earning Management: the Case for the Czech Republic and Slovakia

Table 2. Description of analyzed models measuring earnings management

\begin{tabular}{|c|c|}
\hline Models & Equations \\
\hline Jones model (1991) & $N D A_{i t}-T A_{i t} \quad 1 \quad \Delta R E V_{i t} \quad P P E_{i t}$ \\
\hline Modified Jones & $\begin{array}{l}\frac{A_{i t-1}}{N D A_{i t}}=\frac{A_{i t-1}}{T A_{i t}}=\alpha_{0} \frac{1}{A_{i t-1}}+\alpha_{1} \frac{1}{A_{i t-1}}+\alpha_{2} \frac{1}{A_{i t-1}}+\varepsilon_{i t} \\
\Delta R E V_{i t}-\Delta R E C_{i t}\end{array}$ \\
\hline model (1995) & $\overline{A_{i t-1}}=\overline{A_{i t-1}}=\alpha_{0} \overline{A_{i t-1}}+\alpha_{1} A_{i t-1}+\alpha_{2} \frac{i t}{A_{i t-1}}+\varepsilon_{i t}$ \\
\hline $\begin{array}{lr}\text { Jeter } & \text { and } \\
\text { Shivakumar model }\end{array}$ & $\frac{T A_{i t}}{A_{i t-1}}=\alpha_{0} \frac{1}{A_{i t-1}}+\alpha_{1} \frac{\Delta R E V_{i t}}{A_{i t-1}}+\alpha_{2} \frac{P P E_{i t}}{A_{i t-1}}+\alpha_{3} \frac{C F O_{i t}}{A_{i t-1}}+\varepsilon_{i t}$ \\
\hline Kasznik model & $\frac{N D A_{i t}}{}=\frac{T A_{i t}}{1}=\alpha_{0} \frac{1}{1}+\alpha_{1} \frac{\Delta R E V_{i t}}{1}+\alpha_{2} \frac{P P E_{i t}}{1}+\alpha_{3} \frac{\Delta C F O_{i t}}{1}+\varepsilon_{i t}$ \\
\hline Key model (1997) & 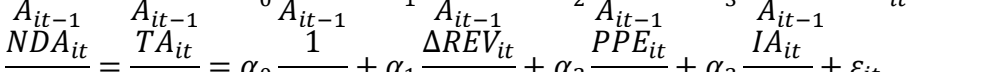 \\
\hline Teoh, Welch and & 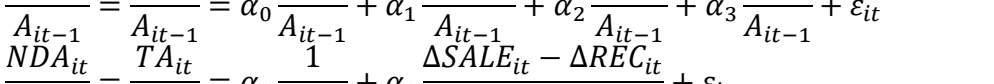 \\
\hline Wong model (1998) & $\overline{A_{i t-1}}=\overline{A_{i t-1}}=\alpha_{0} \overline{A_{i t-1}}+\alpha_{1} \overline{A_{i t-1}}+\varepsilon_{i t}$ \\
\hline Kothari model & $N D A_{i t} T A_{i t}-11 \quad \Delta R E V_{i t}-\triangle R E C_{i t}$ \\
\hline (2005) & $\overline{A_{i t-1}}=\overline{A_{i t-1}}=\alpha_{0} \overline{A_{i t-1}}+\alpha_{1} \overline{A_{i t-1}}+\alpha_{2} \overline{A_{i t-1}}+\alpha_{3} \overline{A_{i t-1}}$ \\
\hline \multirow[t]{11}{*}{ variables } & $T A_{i+}$ \\
\hline & \\
\hline & total assets in the year $\mathrm{t}-1$ \\
\hline & annual change in the value of revenues in the year $t$ \\
\hline & annual change in the value of receivables in the year $t$ \\
\hline & long-term tangible assets in the year $t$ \\
\hline & $\mathrm{CFO}_{i t}$ operating cash flow in the year $\mathrm{t}$ \\
\hline & CFO it-1 operating cash flow in the year $\mathrm{t}-1$ \\
\hline & $I A_{i t} \quad$ long-term intangible assets in the year $\mathrm{t}$ \\
\hline & $\begin{array}{ll}\triangle S A L E_{i t} & \text { annual change in the value of revenues in the year } \mathrm{t} \\
R O A_{i t-1} & \text { return on assets in the year } \mathrm{t}-1\end{array}$ \\
\hline & prediction error \\
\hline
\end{tabular}

Source: developed by the authors based on (Valaskova and Durana, 2020).

Results. The paper assesses the ability of selected earnings models to reveal the earnings manipulation and identify, which of them reflect the country specificities more appropriately. Each model considers different variables. Their descriptive statistics are analysed in Table 3.

The research problem includes the application of several models used to detect the earnings manipulation, based on the linear regression analysis, which is the most commonly used method for detecting earnings management (Hoglund, 2010). All the models described in Table 2 were calculated for every enterprise in each country and subsequently were judged by the determining criteria.

The first criterion is the adjusted $R$ squared coefficient measuring the explanatory power of each earnings model in both countries. Table 4 portrays the overview of this coefficient in individual years under investigation and its mean value.

The adjusted $\mathrm{R}$ squared explains the variability and relevance of analyzed models considering the results in time horizon and among models. The results indicate that the variability of the total accrual changes over the years and its values, in general, are relatively low. However, the Kothari model is the model with the highest level of coefficient of determination and explain, on average, $12.68 \%$ of the total accrual variability. 
T., Kliestik, E., Nica, P., Suler, K., Valaskova. Innovations in the Company's Earning Management: the Case for the Czech Republic and Slovakia

Table 3. Descriptive statistics of assessed variables

\begin{tabular}{|c|c|c|c|}
\hline Descriptive statistics & $\begin{array}{l}\text { Year } \\
2015\end{array}$ & 2016 & 2017 \\
\hline \multicolumn{4}{|c|}{ Total assets [coefficient] } \\
\hline Mean value & 1.1191 & 1.0695 & 1,1269 \\
\hline Standard deviation & 0.3371 & 0.2081 & 0.2435 \\
\hline Median & 1.0641 & 1.0436 & 1.1027 \\
\hline \multicolumn{4}{|l|}{ Receivables [coefficient] } \\
\hline Mean value & 0.2223 & 0.2131 & 0.2242 \\
\hline Standard deviation & 0.2254 & 0.1958 & 0.2020 \\
\hline Median & 0.1712 & 0.1656 & 0.1755 \\
\hline \multicolumn{4}{|l|}{ Sales [coefficient] } \\
\hline Mean value & 1.7031 & 1.5769 & 1.6701 \\
\hline Standard deviation & 1.4725 & 1.2986 & 1.3681 \\
\hline Median & 1.4141 & 1.3174 & 1.3934 \\
\hline \multicolumn{4}{|c|}{ Long-term intangible asset [coefficient] } \\
\hline Mean value & 0.0052 & 0.0048 & 0.0051 \\
\hline Standard deviation & 0.0154 & 0.0141 & 0.0151 \\
\hline Median & 0.0005 & 0.0006 & 0.0006 \\
\hline \multicolumn{4}{|c|}{ Long-term tangible assets [coefficient] } \\
\hline Mean value & 0.3978 & 0.3811 & 0.3982 \\
\hline Standard deviation & 0.3212 & 0.2713 & 0.2814 \\
\hline Median & 0.3652 & 0.3524 & 0.3748 \\
\hline \multicolumn{4}{|l|}{ Return of assets [\%] } \\
\hline Mean value & & 6.2765 & 6.2152 \\
\hline Standard deviation & 7.1066 & 7.1679 & 7.1727 \\
\hline Median & 5.1802 & 4.7892 & 4.9167 \\
\hline \multicolumn{4}{|l|}{ Cash flow [coefficient] } \\
\hline Mean value & 0.1237 & 0.1132 & 0.1175 \\
\hline Standard deviation & 0.0962 & 0.0851 & 0.0895 \\
\hline Median & 0.1045 & 0.0983 & 0.1039 \\
\hline \multicolumn{4}{|l|}{ Net profit [coefficient] } \\
\hline Mean value & 0.0784 & 0.0688 & 0.0716 \\
\hline Standard deviation & 0.0886 & 0.0786 & 0.0821 \\
\hline Median & 0.0563 & 0.0501 & 0.0547 \\
\hline
\end{tabular}

Source: developed by the authors.

Table 4. $R$ squared coefficients by models

\begin{tabular}{lllll}
\hline \multirow{2}{*}{ Model } & \multicolumn{2}{l}{ Adjusted R squared } & \\
& $\mathbf{2 0 1 7}$ & $\mathbf{2 0 1 6}$ & $\mathbf{2 0 1 5}$ & mean \\
\hline Jones & 0.1444 & 0.0792 & 0.0873 & 0.1036 \\
Modified Jones & 0.1494 & 0.0878 & 0.0878 & 0.1083 \\
Jeter and Shivakumar & 0.1463 & 0.0791 & 0.0872 & 0.1042 \\
Kasznik & 0.1467 & 0.0849 & 0.0981 & 0.1099 \\
Key & 0.1487 & 0.0822 & 0.0918 & 0.1076 \\
Teoh, Welch and Wong & 0.0158 & 0.0118 & 0.0042 & 0.0106 \\
Kothari & 0.1592 & 0.1047 & 0.1165 & 0.1268 \\
\hline
\end{tabular}

Source: developed by the authors. 
T., Kliestik, E., Nica, P., Suler, K., Valaskova. Innovations in the Company's Earning Management: the Case for the Czech Republic and Slovakia

Except for Teoh, Welch and Wong model, the R squared of other models exceeds the level of $10 \%$. Despite the fact, that higher values of $R$ squared indicate better explanation power of the model, $a$ lot of quality data can be generated with low R-squared as discussed in the studies of Barclay (1991) or Locke and Wellelage (2014). Predicted sign of variables reveals the relation between the expectations of the coefficients of specific variable value (calculated in the regression analysis) with the real value achieved. The mutual match is judged in each year, and the average values are portrayed, Table 5.

Table 5. Predicted sign of variables by models

\begin{tabular}{|c|c|c|c|c|c|}
\hline Model & Prediction & 2017 & 2016 & 2015 & $\%$ success \\
\hline \multicolumn{6}{|l|}{ Jones model } \\
\hline$\Delta \mathrm{REV}$ & + & - & - & - & $0 \%$ \\
\hline PPE & - & - & - & - & $100 \%$ \\
\hline \multicolumn{6}{|c|}{ Modified Jones model } \\
\hline$\Delta \mathrm{REV}-\Delta \mathrm{REC}$ & + & - & - & - & $0 \%$ \\
\hline PPE & - & - & - & - & $100 \%$ \\
\hline \multicolumn{6}{|c|}{ Jeter and Shivamkumar model } \\
\hline$\Delta \mathrm{REV}$ & + & - & - & - & $0 \%$ \\
\hline PPE & - & - & - & - & $100 \%$ \\
\hline CF & - & + & - & + & $33 \%$ \\
\hline \multicolumn{6}{|l|}{ Kasznik model } \\
\hline$\Delta \mathrm{REV}$ & + & - & - & - & $0 \%$ \\
\hline PPE & - & - & - & - & $100 \%$ \\
\hline$\Delta \mathrm{CF}$ & - & + & + & + & $0 \%$ \\
\hline \multicolumn{6}{|l|}{ Key model } \\
\hline$\triangle \mathrm{REV}$ & + & - & - & - & $0 \%$ \\
\hline PPE & - & - & - & - & $100 \%$ \\
\hline IA & - & - & - & - & $100 \%$ \\
\hline \multicolumn{6}{|c|}{ Teoh, Welch and Wong model } \\
\hline$\Delta \mathrm{REV}-\Delta \mathrm{REC}$ & + & - & - & - & $0 \%$ \\
\hline \multicolumn{6}{|l|}{ Kothari model } \\
\hline$\Delta \mathrm{REV}-\Delta \mathrm{REC}$ & + & - & - & - & $0 \%$ \\
\hline $\mathrm{ROA}$ & - & - & - & - & $100 \%$ \\
\hline PPE & - & + & + & + & $100 \%$ \\
\hline
\end{tabular}

Source: developed by the authors.

Analyzing the results, none of the models meets the predicted sign of all estimated parameters. Thus, judging the detection models using the criterion of the predicted sign is not reliable. The most problematic is the variable dedicated to the changes if the value of revenues, which is the most important indicator, and thus the results of this criterion would not be considered in the final assessment of the model.

Standard deviation characterizes the variability of variables in each model and compares the results of standard deviations and values on variables by models. However, to ensure the lucidity of the results, Table 6 summarizes the comparison based on the mean values.

Low values of standard deviation demonstrate that the data are very close to the mean value. The model is better to explain the issue of earnings manipulation. Thus, only those models are accepted, whose change in the standard deviation of all independent variables does not exceed $15 \%$. Three models meet the requirements, modified Jones model, Teoh, Welch and Wong model and Kothari model.

Following the last criterion, the significance level of each model and its variables, the truthfulness of results is evaluated. The significance of the model was considered, based on the value of significance $F$ of ANOVA test and the significant variables were detected using the $p$-values of coefficients of variables 
T., Kliestik, E., Nica, P., Suler, K., Valaskova. Innovations in the Company's Earning Management: the Case for the Czech Republic and Slovakia

- the results were compared with the significance level. In the monitored period 2015-2017, all analysed earnings models appear to be statistically significant.

Table 6. Standard deviation and mean values of variables by models and countries

\begin{tabular}{|c|c|c|c|}
\hline Model / Mean values & Coeff. & St.dev & change $\%$ \\
\hline \multicolumn{4}{|l|}{ Jones model } \\
\hline intercept & 0.0265 & 0.0040 & \\
\hline$\Delta \mathrm{REV}$ & -0.0271 & 0.0051 & 18.82 \\
\hline PPE & -0.1858 & 0.0079 & 4.25 \\
\hline \multicolumn{4}{|l|}{ Modified Jones model } \\
\hline intercept & 0.0284 & 0.0039 & \\
\hline$\Delta \mathrm{REV}-\Delta \mathrm{REC}$ & -0.0461 & 0.0054 & 11.71 \\
\hline PPE & -0.1866 & 0.0079 & 4.23 \\
\hline \multicolumn{4}{|c|}{ Jeter and Shivakumar model } \\
\hline intercept & 0.0226 & 0.0048 & \\
\hline$\triangle \mathrm{REV}$ & -0.0284 & 0.0053 & 18.66 \\
\hline PPE & -0.1871 & 0.0080 & 4.28 \\
\hline CF & 0.0371 & 0.0263 & 70.89 \\
\hline \multicolumn{4}{|l|}{ Kasznik model } \\
\hline intercept & 0.0266 & 0.0039 & \\
\hline$\Delta \mathrm{REV}$ & -0.0356 & 0.0054 & 15.17 \\
\hline PPE & -0.1886 & 0.0079 & 4.19 \\
\hline$\Delta \mathrm{CF}$ & 0.2045 & 0.0368 & 17.99 \\
\hline \multicolumn{4}{|l|}{ Key model } \\
\hline intercept & 0.0313 & 0.0041 & \\
\hline$\Delta \mathrm{REV}$ & -0.0264 & 0.0051 & 19.32 \\
\hline PPE & -0.1886 & 0.0079 & 4.19 \\
\hline IA & -0.5708 & 0.1564 & 27.40 \\
\hline \multicolumn{4}{|c|}{ Teoh, Welch and Wong model } \\
\hline intercept & $-0-0460$ & 0.0025 & \\
\hline$\Delta \mathrm{REV}-\Delta \mathrm{REC}$ & -0.0405 & 0.0057 & 14.07 \\
\hline \multicolumn{4}{|l|}{ Kothari model } \\
\hline intercept & 0.0061 & 0.0047 & \\
\hline$\Delta \mathrm{REV}-\Delta \mathrm{REC}$ & -0.0532 & 0.0054 & 10.15 \\
\hline ROA & -0.1768 & 0.0079 & 4.47 \\
\hline PPE & 0.0029 & 0.0003 & 10.34 \\
\hline
\end{tabular}

Source: developed by the authors.

The same result is observed when assessing the statistical significance of individual variables in the reference years, when all variables are calculated as statistically significant, except for the Jeter and Shivakumar model, which shows statistical insignificance for the cash flow variable in 2016 and 2017. Thus, the percentage of statistical significance is only $33.33 \%$.

The analysis of 6,997 Slovak and Czech enterprises proves that the Kothari model seems to be the most appropriate to detect earnings management. Thus, using the equation of this model, the discretionary accruals were calculated. Figure 1 portrays the level of manipulation and its direction in individual enterprises of both countries.

Enterprises do not manipulate earnings if the value of discretionary accruals is zero (light orange line in Figure 1). To confirm that there are statistically significant differences in the level of manipulation in the investigated period, the data of both countries were analysed in the Friedman test, Table 7. 
T., Kliestik, E., Nica, P., Suler, K., Valaskova. Innovations in the Company's Earning Management: the Case for the Czech Republic and Slovakia

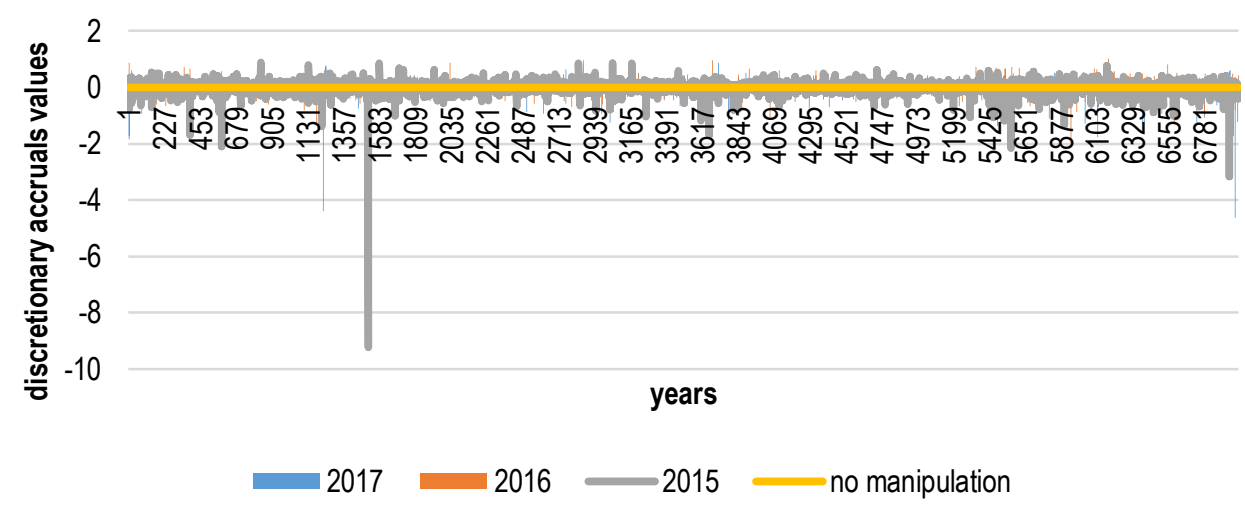

Figure 1. Earnings management in Slovakia and Czechia

Source: developed by the authors.

Table 7. Mean ranks of Friedman's two-way analysis of variance

\begin{tabular}{lll}
\hline & & Friedman \\
\hline Sig. & & 0.000 \\
Mean rank & 2015 & 2.02 \\
& 2016 & 1.88 \\
& 2017 & 1.93 \\
\hline
\end{tabular}

Source: developed by the authors.

Assessing the means ranks of Friedman test, there was a gradual decrease in the manipulation of earnings between 2015 and 2016 with a slight decrease in 2017. The changes in the manipulation of earnings might be a consequence of the decrease in the volume of gross domestic product (annual rate of change) in 2016/2017. These results are also confirmed in the study of Habib et al. (2012). They claim that management of unhealthy (unstable) enterprises tends to practise income-decreasing manipulation of earnings compared to their healthy (stable) firm counterparts. The gross fixed capital formation was negative in 2016 (increasing again in 2017) explaining that the new value-added in the economy is consumed rather than invested. The negative development of gross domestic product challenged managers to maintain the stability of enterprises (Sosnowski, 2018). Besides, the findings of Lisboa and Kacharava (2018) suggest that inauspicious development has an impact on the corporate tendency to manage financial results. However, the country effect is not statistically. It is in divergence with the study of Geiger et al. (2006) who confirm that perception of earnings management differs across countries. The results indicate that enterprises tend to manipulate earnings. However, the extent of manipulation differs throughout the years. The sign of manipulation is given by the proportional ratio of companies with the positive or negative sign of calculated discretionary accruals to the total number of companies. Table 8 summarizes the percentage of companies with positive and negative discretionary accruals (DA) in each year and the mean value.

Table 8. Discretionary accruals in enterprises

\begin{tabular}{llcll}
\hline & $\mathbf{2 0 1 5}$ & $\mathbf{2 0 1 6}$ & $\mathbf{2 0 1 7}$ & Mean value \\
\hline \% of enterprises + DA & $65.16 \%$ & $53.08 \%$ & $55.45 \%$ & $57.90 \%$ \\
$\%$ of enterprises - DA & $34.84 \%$ & $46.92 \%$ & $44.55 \%$ & $42.10 \%$ \\
\hline
\end{tabular}

Source: developed by the authors. 
T., Kliestik, E., Nica, P., Suler, K., Valaskova. Innovations in the Company's Earning Management: the Case for the Czech Republic and Slovakia

Comparing the share of positive and negative accruals, more than half of the companies operating in both countries tend to manipulate earnings upwards, as the ratio of positive discretionary accruals exceeds the ratio of negative discretionary accruals. Once the direction of the manipulation with earnings is determined, the magnitude of manipulation, using the average values of discretionary accruals, is calculated. The average values, expressed as a coefficient, are given in Table 9.

Table 9. Calculation of the earnings management magnitude

\begin{tabular}{lllll}
\hline & $\mathbf{2 0 1 5}$ & $\mathbf{2 0 1 6}$ & $\mathbf{2 0 1 7}$ & mean \\
\hline Mean value +DA & 0.1074 & 0.0797 & 0.0834 & 0.0902 \\
Mean value -DA & 0.1311 & 0.1026 & 0.1040 & 0.1126 \\
Difference (+DA-(-DA)) & -0.0238 & -0.0228 & -0.0206 & -0.0224
\end{tabular}

Source: developed by the authors.

The average value of the discretionary (negative) accrual in 2015 is higher than the average value of the discretionary (positive) accrual. Comparing the average values of discretionary accruals in 2016, the average value of the discretionary (negative) accrual is again higher than the average value of the discretionary (positive) accrual. There was no change in 2017, which suggests that in each year, the manipulation of profits by decreasing it is more considerable than manipulating profits by increasing earnings. The determination of the presence of earnings management may help reveal the motives of earnings manipulation. One of the most relevant incentives is taxation. Enterprises manipulate earnings downwards to decrease their tax expenses calculated based on the volume of total earnings (Van Tendeloo and Vanstraelen, 2008). El Diri (2018) alerted that taxation mitigates aggressive earnings management as huge differences between book income. In turn, a tax income can be easily noticed by the tax authorities. Moreover, the flexibility in tax laws gives a chance to manage earnings, for instance, allowing income adjustments for tax purposes drives enterprises to manage earnings downwards. Herewith, reducing taxes over specific periods in the future drives enterprises to shift earnings forward (Gramlich, 1991; Maydew, 1997 in El Diri, 2018). The influence of one- and two-book systems on earnings management is discussed by Watrin et al. (2014). In the research of Godsell et al. (2017), the basic incentives of earnings management are clearly identified; accounting data directly affect the tariffs imposed in the trade investigation. On the contrary, the tendency to engage in earning management is also given by the cultural factors, which remain influential in explaining differences in the magnitude of earnings management among different countries (Gray et al., 2015). Also, the macroeconomic development of the countries plays an important role, which is in detailed portrayed in the study of Dimitras et al. (2015) and Reverte (2008).

Conclusions. Earnings management emphasizes the motives of corporate managers to manipulate earnings under different conditions and to meet the personal objectives of managers, defined corporate strategies and tasks, and fulfil the innovation strategy of enterprises. Earnings management is a complex process that involves the accounting judgment that underlies not only the income statement but also the other financial statements and related disclosures. It also involves the structuring of business decisions.

Assessment of different earnings management models proves that the Kothari model is the most appropriate to estimate the non-discretionary accruals in Slovak and Czech enterprises. The mean value shows that $58 \%$ of analysed enterprises tend to manage earnings to increase them. The level of the manipulation, given by the absolute values of discretionary accruals, indicates that the downward manipulation is significantly higher than the upward manipulation. The manipulation changes extent over the years because of the changed market environment in the countries. The future direction of the research may solve the limitations of the study. The attempt is to use the non-linear regression models, or neural networks to assess the problems with earnings management in enterprises as well as extend the database 
T., Kliestik, E., Nica, P., Suler, K., Valaskova. Innovations in the Company's Earning Management: the Case for the Czech Republic and Slovakia

of enterprises of more countries (considering various groupings of countries) or, vice versa, divide the enterprises according to the size, business orientation or industry sector. Thus, there should be a continuous focus on the issue of earnings management to unveil divergent earnings management techniques to protect investors from financial risk due to distorted information.

Author Contributions: conceptualization, K. V.; methodology, T. K. and K. V.; software, E. N.; validation, E. N. and P. S.; formal analysis, K. V. and E. N.; investigation, T. K. and P. S.; resources, T. K.; data curation, K. V.; writing-original draft preparation, T. K. and K. V.; writing-review and editing, K. V. and E. N.; visualization, P. S.; supervision, E. N.; project administration, T. K.; funding acquisition, K. V. and T. K.

Funding. This research was financially supported by the Slovak Research and Development Agency - Grant NO. APVV-17-0546: Variant Comprehensive Model of Earnings Management in Conditions of the Slovak Republic as an Essential Instrument of Market Uncertainty Reduction.

\section{References}

Alhadab, M., Clacher, I. \& Keasey, K. (2015).Real and accrual earnings management and IPO failure risk. Accounting and Business research, 45(1): 55-92. [Google Scholar] [Google Scholar]

Barclay, D. L. (1991). A statistical note on trend factors: The meaning of R-squared. Casualty Actuarial Society Forum, 2, 7-18. [Google Scholar]

Barth, M., \& Taylor, D. (2010). In defense of fair value: Weighing the evidence on earnings management and asset securitizations. Journal of Accounting and Economics, 49(1-2), 26-33. [Google Scholar] [CrossRef]

Beneish, M. D. (1997). Detecting GAAP violation: Implications for assessing earnings management among firms with extreme financial performance. Journal of accounting and public policy, 16(3), 271-309. [Google Scholar] [Google Scholar]

Burgstahler, D., \& Dichev, I. (1997). Earnings management to avoid earnings decreases and losses. Journal of accounting and economics, 24(1), 99-126. [Google Scholar] [CrossRef]

Burgstahler, D. C., Hail, L., \& Leuz, C. (2006). The importance of reporting incentives: Earnings management in European private and public firms. The accounting review, 81(5), 983-1016. [Google Scholar] [CrossRef]

Callao, S., \& Jarne, J. I. (2010). Have IFRS affected earnings management in the European Union?. Accounting in Europe, 7(2), 159-189. [Google Scholar] [CrossRef]

Campa, D. (2019). Earnings management strategies during financial difficulties: A comparison between listed and unlisted French companies. Research in International Business and Finance, 50, 457-471. [Google Scholar] [CrossRef]

Chen, S. K., Lin, B. X., Wang, Y., \& Wu, L. (2010). The frequency and magnitude of earnings management: Time-series and multi-threshold comparisons. International Review of Economics \& Finance, 19(4), 671-685. [Google Scholar] [CrossRef]

Chen, S., Cai, W., \& Jebran, K. (2019). Does social trust mitigate earnings management? Evidence from China. Emerging Markets Finance and Trade, 1-22. [Google Scholar] [CrossRef]

Cimini, R. (2015). How has the financial crisis affected earnings management? A European study. Applied economics, 47(3), 302-317. [Google Scholar] [CrossRef]

Collins, D. W., Pungaliya, R. S., \& Vijh, A. M. (2017). The effects of firm growth and model specification choices on tests of earnings management in quarterly settings. The Accounting Review, 92(2), 69-100. [Google Scholar] [CrossRef]

DeAngelo, H., DeAngelo, L., \& Skinner, D. J. (1994). Accounting choice in troubled companies. Journal of Accounting and Economics, 17(1-2), 113-143. [Google Scholar] [CrossRef]

DeAngelo, L. E. (1986). Accounting numbers as market valuation substitutes: A study of management buyouts of public stockholders. Accounting review, 400-420. [Google Scholar]

DeFond, M. L., \& Jiambalvo, J. (1994). Debt covenant violation and manipulation of accruals. Journal of accounting and economics, 17(1-2), 145-176. [Google Scholar] [CrossRef

Degeorge, F., Patel, J., \& Zeckhauser, R. (1999). Earnings management to exceed thresholds. The Journal of Business, 72(1), 1-33. [Google Scholar] [CrossRef]

Dechow, P. M., \& Sloan, R. G. (1991). Executive incentives and the horizon problem: An empirical investigation. Journal of accounting and Economics, 14(1), 51-89. [Google Scholar] [CrossRef

Dechow, P. M., \& Dichev, I. D. (2002). The quality of accruals and earnings: The role of accrual estimation errors. The accounting review, 77(s-1), 35-59. [Google Scholar] [CrossRef]

Dechow, P. M., Sloan, R. G., \& Sweeney, A. P. (1995). Detecting earnings management. Accounting review, 193-225. [Google Scholar]

Dimitras, A. I., Kyriakou, M. I., \& latridis, G. (2015). Financial crisis, GDP variation and earnings management in Europe. Research in International Business and Finance, 34, 338-354. [Google Scholar] [CrossRef] 
T., Kliestik, E., Nica, P., Suler, K., Valaskova. Innovations in the Company's Earning Management: the Case for the Czech Republic and Slovakia

Ding, R., Li, J., \& Wu, Z. (2018). Government affiliation, real earnings management, and firm performance: The case of privately held firms. Journal of Business Research, 83, 138-150. [Google Scholar] [CrossRef]

Dunmore, P. (2013). Some models for the evolution of financial statement data. New Zealand: Massey University. Retrieved from

https://www.massey.ac.nz/massey/fms/Colleges/College \%20of\%20Business/School\%20of\%20Accountancy/Documents/Discussio n\%20Papers/223.pdf

El Diri, M. (2018). Introduction to earnings management. Switzerland: Springer. [Google Scholar]

Hamza, S. E., \& Kortas, N. (2019). The interaction between accounting and real earnings management using simultaneous equation model with panel data. Review of Quantitative Finance and Accounting, 53(4), 1195-1227. [Google Scholar] [CrossRef]

Godsell, D., Welker, M., \& Zhang, N. (2017). Earnings Management During Antidumping Investigations in Europe: SampleWide and Cross-Sectional Evidence. Journal of Accounting Research, 55(2), 407-457. [Google Scholar] [CrossRef]

Gramlich, J. (1991). The effect of the alternative minimum tax book income adjustment on accrual decisions. Journal of the American Taxation Association, 13(1), 36-56. [Google Scholar]

Gray, S. J., Kang, T., Lin, Z., \& Tang, Q. (2015). Earnings management in Europe post IFRS: Do cultural influences persist? Management International Review, 55(6), 827-856. [Google Scholar] [CrossRef]

Geiger, M. A., O'Connell, B. T., Clikeman, P. M., Ochoa, E., Witkowski, K., \& Basioudis, I. (2006). Perceptions of earnings management: The effects of national culture. Advances in International Accounting, 19, 175-199. [Google Scholar] [CrossRef]

Gunny, K. A. (2010). The relation between earnings management using real activities manipulation and future performance: Evidence from meeting earnings benchmarks. Contemporary accounting research, 27(3), 855-888. [Google Scholar] [CrossRef]

Habib, A., Bhuiyan, B. U., \& Islam, A. (2013). Financial distress, earnings management and market pricing of accruals during the global financial crisis. Managerial Finance. [Google Scholar] [CrossRef]

Healy, P. M. (1985). The effect of bonus schemes on accounting decisions. Journal of accounting and economics, 7(1-3), 85107. [Google Scholar] [CrossRef]

Healy, P. M., \& Wahlen, J. M. (1999). A review of the earnings management literature and its implications for standard setting. Accounting horizons, 13(4), 365-383. [Google Scholarl] [CrossRef]

Hepworth, S. R. (1953). Smoothing periodic income. The accounting review, 28(1), 32-39. [Google Scholar]

Hribar, P., \& Collins, D. W. (2002). Errors in estimating accruals: Implications for empirical research. Journal of Accounting research, 40(1), 105-134. [Google Scholar] [CrossRef] Scholarl

Hoglund, H. (2010). Detecting earnings management using neural networks. Finland: Hanken School of Economics. [Google

Holthausen, R. W., Larcker, D. F., \& Sloan, R. G. (1995). Annual bonus schemes and the manipulation of earnings. Journal of accounting and economics, 19(1), 29-74. [Google Scholar] [CrossRef]

Jeanjean, T., \& Stolowy, H. (2008). Do accounting standards matter? An exploratory analysis of earnings management before and after IFRS adoption. Journal of accounting and public policy, 27(6), 480-494. [Google Scholar] [CrossRef]

Jeter, D. C., \& Shivakumar, L. (1999). Cross-sectional estimation of abnormal accruals using quarterly and annual data: Effectiveness in detecting event-specific earnings management. Accounting and Business Research, 29(4), 299-319. [Google Scholar] [CrossRef]

Jones, J. J. (1991). Earnings management during import relief investigations. Journal of accounting research, 29(2), 193-228. [Google Scholar] [CrossRef]

Kasznik, R. (1999). On the association between voluntary disclosure and earnings management. Journal of accounting research, 37(1), 57-81. [Google Scholarl [CrossRef]

Key, K. G. (1997). Political cost incentives for earnings management in the cable television industry. Journal of accounting and economics, 23(3), 309-337. [Google Scholar] [CrossRef]

Klein, A. (2002). Audit committee, board of director characteristics, and earnings management. Journal of accounting and economics, 33(3), 375-400. [Google Scholar] [CrossRef]

Kothari, S. P., Leone, A. J., \& Wasley, C. E. (2005). Performance matched discretionary accrual measures. Journal of accounting and economics, 39(1), 163-197. [Google Scholar] [CrossRef]

Kothari, S. P., Mizik, N., \& Roychowdhury, S. (2016). Managing for the moment: The role of earnings management via real activities versus accruals in SEO valuation. The Accounting Review, 91(2), 559-586. [Google Scholar] [CrossRef]

Krajnak, M. (2019). Do Selected Tax Advantages Affect Tax Revenue from the Personal Income Tax? Journal of Competitiveness, 11(4), 73-88. [Google Scholar] [CrossRef]

Larcker, D. F., \& Richardson, S. A. (2004). Fees paid to audit firms, accrual choices, and corporate governance. Journal of accounting research, 42(3), 625-658. [Google Scholar] [CrossRef]

Leuz, C., Nanda, D., \& Wysocki, P. D. (2003). Earnings management and investor protection: an international comparison. Journal of financial economics, 69(3), 505-527. [Google Scholar] [CrossRef]

Lisboa, I., \& Kacharava, A. (2018). Does financial crisis impact earnings management evidence from Portuguese and UK. European Journal of Applied Business and Management, 4(1). [Google Scholar]

Lo, K., Ramos, F., \& Rogo, R. (2017). Earnings management and annual report readability. Journal of Accounting and Economics, 63(1), 1-25. [Google Scholar] [CrossRef] 
T., Kliestik, E., Nica, P., Suler, K., Valaskova. Innovations in the Company's Earning Management: the Case for the Czech Republic and Slovakia

Locke, S.M. \& Wellalage, N.H. (2014). The capital structure of Sri Lankan companies: A quantile regression analysis. Journal of Asia-Pacific Business, 15(3): 211-230. [Google Scholar] [CrossRef]

Maydew, E. L. (1997). Tax-induced earnings management by firms with net operating losses. Journal of Accounting Research, 35(1), 83-96. [Google Scholar] [CrossRef]

McNichols, M., \& Wilson, G. P. (1988). Evidence of earnings management from the provision for bad debts. Journal of accounting research, 1-31. [Google Scholar] [CrossRef]

McNichols, M. F. (2000). Research design issues in earnings management studies. Journal of accounting and public policy, 19(4-5), 313-345. [Google Scholar] [CrossRef]

McNichols, M. F. (2002). Discussion of the quality of accruals and earnings: The role of accrual estimation errors. The accounting review, 77(s-1), 61-69. [Google Scholar] [CrossRef]

Nwaeze, E. T. (2011). Are incentives for earnings management reflected in the ERC: Large sample evidence. Advances in accounting, 27(1), 26-38. [Google Scholar] [CrossRef]

Okamoto, N. (2011). Collective intentionality and aggressive earnings management: Developing Norman Macintosh's arguments in the debate over principles-versus rules-based accounting standards. Critical Perspectives on Accounting, 22(2), 236242. [Google Scholar] [CrossRef]

Pae, J. (2005). Expected accrual models: the impact of operating cash flows and reversals of accruals. Review of Quantitative Finance and Accounting, 24(1), 5-22. [Google Scholar] [CrossRef]

Peasnell, K. V., Pope, P. F., \& Young, S. (2000). Detecting earnings management using cross-sectional abnormal accruals models. Accounting and Business research, 30(4), 313-326. [Google Scholar] [CrossRef]

Reverte, C. (2008). Institutional differences in EU countries and their relationship with earnings management differences. Journal of Accounting \& Organizational Change. [Google Scholar] [CrossRef]

Rodrigues, L., Marques M. \& Craig, R. (2011). Earnings management induced by tax planning: The case of Portuguese private firms. Journal of International Accounting, Auditing and Taxation, 20, 83- 96. [Google Scholar] [CrossRef]

Ronen, J., \& Sadan, S. (1981). Smoothing income numbers: Objectives, means, and implications. Addison-Wesley Publishing Company.

Roychowdhury, S. (2006). Earnings management through real activities manipulation. Journal of accounting and economics, 42(3), 335-370. [Google Scholar] [CrossRef]

Schipper, K. (1989). Earnings management. Accounting horizons, 3(4), 91. [Google Scholar]

Skinner, D. J., \& Sloan, R. G. (2002). Earnings surprises, growth expectations, and stock returns or don't let an earnings torpedo sink your portfolio. Review of accounting studies, 7(2-3), 289-312. [Google Scholar] [CrossRef]

Sosnowski, T. (2018). Earnings management in the private equity divestment process on Warsaw Stock Exchange. Equilibrium. Quarterly Journal of Economics and Economic Policy, 13(4), 689-705. [Google Scholar]

Spathis, C. T. (2002). Detecting false financial statements using published data: some evidence from Greece. Managerial Auditing Journal. [Google Scholar] [CrossRef]

Stefko, R., Jencova, S., Vasanicova, P., \& Litavcova, E. (2019). An evaluation of financial health in the electrical engineering industry. Journal of Competitiveness, 11(4), 144. [Google Scholar] [CrossRef]

Stubben, S. R. (2010). Discretionary revenues as a measure of earnings management. The accounting review, 85(2), 695-717. [Google Scholar] [CrossRef]

Teoh, S. H., Welch, I., \& Wong, T. J. (1998). Earnings management and the underperformance of seasoned equity offerings. Journal of Financial economics, 50(1), 63-99. [Google Scholar] [CrossRef]

Valaskova, K., \& Durana, P. (2020). Global context of disparities in earnings management among enterprises: Evidence from Slovakia. In SHS Web of Conferences (Vol. 74, p. 01034). EDP Sciences. [Google Scholarl [CrossRef]

Van Tendeloo, B., \& Vanstraelen, A. (2008). Earnings management and audit quality in Europe: Evidence from the private client segment market. European accounting review, 17(3), 447-469. [Google Scholar] [CrossRef]

Watrin, C., Ebert, N., \& Thomsen, M. (2014). Book-tax conformity and earnings management: insights from European one-and two-book systems. The Journal of the American Taxation Association, 36(2), 55-89. [Google Scholar] [CrossRef]

Watts, R. \& Zimmerman, J. (1986). Positive accounting theory. Englewood Cliffs, New Jersey: Prentice Hall. [Google Scholar]

Xie, B., Davidson III, W. N., \& DaDalt, P. J. (2003). Earnings management and corporate governance: the role of the board and the audit committee. Journal of corporate finance, 9(3), 295-316. [Google Scholar] [CrossRef]

Yagüe, J., Gómez-Sala, J. C., \& Poveda-Fuentes, F. (2009). Stock split size, signaling and earnings management: Evidence from the Spanish market. Global Finance Journal, 20(1), 31-47. [Google Scholar] [CrossRef]

Ye, J. (2007). Accounting Accruals and Tests of Earnings Management. Baruch College, 1-45. [Google Scholarl [CrossRef]

Yoon, S. S., \& Miller, G. (2002). Earnings management of seasoned equity offering firms in Korea. The international journal of accounting, 37(1), 57-78. [Google Scholar] [CrossRef]

Zang, A. Y. (2012). Evidence on the trade-off between real activities manipulation and accrual-based earnings management. The accounting review, 87(2), 675-703. [Google Scholar] [CrossRef] 
T., Kliestik, E., Nica, P., Suler, K., Valaskova. Innovations in the Company's Earning Management: the Case for the Czech Republic and Slovakia

Томас Клієстік, професор, Жилінський університет, Словацька республіка

Ельвіра Ніца, професор, Економічна академія в Бухаресті, Румунія

Пітер Сулер, Ph.D., Iнститут технологій і бізнесу в Чеських Будейовииях, Чеська Республіка

Катаріна Валаскова, Ph.D., Жилінський університет, Словацька Республіка

Інновації в системі управління доходами компанії: досвід Чехії та Словаччини

У статті проаналізовано сучасні інструменти управління доходами компанії. Авторами зазначено, що проблеми маніпуляцій у бухгалтерській звітності це наслідок неефективних управлінських рішень щодо максимізації прибутку без звітування у короткостроковій перспективі. У статті наголошено, що така практика спрямована на внесення змін до фінансової звітності з метою викривлення інфформації для стейкхолдерів компанії. Зазначено, що, як правило, маніпуляції із бухгалтерською звітністю найчастіше відбуваються на етапі подачі звітності та руху грошових потоків, тобто при опортуністичному стилі ведення бухгалтерської звітності. У статті розглянуто можливості виявлення, кількісного оцінювання ступеня та масштабу спотворення бухгалтерської звітності на прикладі словацьких та чеських компаній. Періодом дослідження обрано 2015-2017 роки. Головною метою дослідження $є$ систематичний аналіз особливостей маніпуляцій у бухгалтерській звітності з урахуванням суперечливої інноваційної політики підприємств щодо управління доходами. Для досягнення поставленої мети у статті обгрунтовано низку підходів до розуміння проблеми маніпуляцій у буххалтерській звітності. Авторами запропоновано методологічні рекомендації для виявлення вище зазначених випадків та їх кількісного оцінювання. Емпіричний аналіз базується на даних 2155 словацьких та 4842 чеських підприємств. У ход дослідження здійснено експертну оцінку 29 моделей виявлення випадків спотворення бухгалтерської звітності. Зокрема, найефективнішою визначено модель Котарі. Перевірку тенденції, ступеню та масштабу спотворення бухгалтерської звітності здійснено за допомогою непараметричного тесту Фрідмана. Результати аналізу свідчать про те, що на національному рівні маніпуляиії простежуються в завищенні доходів. Авторами наголошено, що забезпечення реальних даних фінансової звітності дозволить підприємству уникнути будь-яких фінансових та кредитних ризиків, то виявлення випадків спотворення бухгалтерської звітності на підприємстві відіграє значну роль.

Ключові слова: бухгалтерська звітність, модель виявлення маніпуляцій у бухгалтерській звітності, дискреційні нарахування.

Manuscript received: 13.04 .2020

(C) The author(s) 2020. This article is published with open access at Sumy State University. 